\title{
Moderation of risk preferences on factors influencing MSME taxpayer compliance in Indonesian digital transactions
}

\author{
Waluyo $^{a^{*}}$ and Susila Hesti Purnami ${ }^{a}$
}

\begin{tabular}{l} 
a Department of Accounting, Universitas \\
\hline C H R O N I C L E \\
\hline Article history: \\
Received August 20, 2021 \\
Received in revised format \\
September 272021 \\
Accepted October 182021 \\
Available online \\
October 182021 \\
\hline Keywords: \\
MSME tax compliance \\
Tax knowledge \\
Tax sanctions \\
Peer influence \\
Tax authority service quality \\
Risk preference
\end{tabular}
\begin{abstract}
A B S T R A C T
The advancement of digital technology encourages the growth of MSMEs transacting online. However, the phenomenon shows that the Indonesian tax ratio declines because the tax compliance increase rate does not accompany the potential tax base growth. This study analyzed the determining factors of tax compliance: tax knowledge, tax sanctions, peer influence, and the quality of tax authority services moderated by risk preferences. Because of the data analysis, it was discovered that only tax knowledge had a clear impact and risk preferences had no significant influence on the factors that influenced MSME tax compliance in digital transactions. Limited information circulating citizens about MSME-specific policies in digital commerce and rules that have not been communicated in online marketplaces are the main tasks for tax authorities in Indonesia. This study proposes a model of MSME's tax compliance in a digital transaction.
\end{abstract}

\section{Introduction}

The surge in tax receipts over the last five years is not in line with the tax ratio in Indonesia. The Indonesian Tax Authority issued a tax ratio report between 2010 - 2019 in March 2019, followed by a statement that local taxes such as Land and Buildings Tax are excluded from calculating the state tax ratio. The tax ratio recorded by the Ministry of Finance was $11.5 \%$ in 2018 and $12.2 \%$ in 2019. Compared to the average tax ratio of other countries in the Asia Pacific, the amount is low because the figure is smaller than regional and global standards, so the Indonesian tax authorities are working on expanding the tax base (Direktorat Jenderal Pajak, 2019). These efforts have a stimulating effect and are proven by the increasing number of tax receipts in 2019, with a total of Rp 1,545.3 trillion. The amount meets $86.5 \%$ of the target tax receipts of Rp 1,786.4 trillion. Despite a $0.8 \%$ increase in the tax ratio within one year, the Indonesian tax authorities cannot be proud because taxpayer compliance remains low. An independent tax consulting firm, DDTC, published the realization of the 2019 State Budget in January 2020, and the report implies a shortfall in tax receipts of around Rp 245.5 trillion. The percentage of taxpayer compliance in the annual authority performance report decreased from $63.15 \%$ in 2016 to $62.96 \%$ in 2017. A new query has formed why the more significant tax base that should bring in higher state revenues has come with declining compliance rates from taxpayers. Indonesia's more extensive tax base is derived from rapid business growth and inseparable from increasingly productive economic activities, especially the growing MSME sector. The statistics of MSMEs issued by the Cooperative Ministry from 2016 to 2017 increased by 2.06\% or 1,271,440 units making MSMEs a potential target for more tax receipts. MSMEs dominate the Indonesian economy with $98.8 \%$ of total business units, $96.99 \%$ of the entire workforce, and $60.3 \%$ GDP. The final income tax of $1 \%$ of MSMEs contributed $2.2 \%$ to complete income tax * Corresponding author.

E-mail address: waluyo@mercubuana.ac.id (Waluyo) 
receipts in 2017 (Mutmainah, 2016). From the taxation of MSME income, it was found that the amount of income tax paid by individual MSMEs is higher than the payments made by corporate MSME taxpayers. Government Regulation No. 46 of 2013 is considered to have some shortcomings, so it needs to be tailored and aligned with the present economic situation. The reduction of the final CIT rate from 1\% to $0.5 \%$ in Government Regulation No. 23 of 2018 becomes an option because corporate taxpayers can choose either to follow the final rate or the typical scheme of income tax article 17 in Law No. 36 of 2008 (Sarpingah et al., 2017). The growth in tax compliance rates is the result of a variety of factors, including tax knowledge. Tax knowledge is advice for taxpayers that supports operating, taking arrangements, and pursuing positive directives or approaches concerning the enforcement of their tax rights and responsibilities. From this definition, when MSME taxpayers own sufficient data, they will take advantage of information to fulfill their fiscal obligations. This is supported by tax research which indicates that awareness of taxes has a massive impact on the complaisance of Nigerian MSME taxpayers. (Alabede et al., 2011) The strong effect of tax knowledge on Indonesian MSME tax compliance in 2015 is another supporting finding, including the SME tax compliance research done in 2018 (Waluyo, 2018). But the different results being found by researchers in Indonesia that tax knowledge negatively impacts taxpayer compliance (Rediyana \& Mulya, 2019).

Having adequate taxation knowledge does not guarantee that MSME taxpayers comply personally and carry out their obligations. MSME taxpayers who already know the rules of taxation have the potential to use their knowledge to avoid taxation by exploiting loopholes. And to minimize this, the tax authority uses preventive measures in the form of tax sanctions to raise fears from taxpayers to use their knowledge in matters that harm the country. This tax sanction is a preventative and controlling tool conducted by the government to boost tax compliance, as evidenced by the research results from the observance of individual taxpayers with studies in Bandung (Kamil, 2015) that are significantly affected by tax sanctions - then supported by research conducted in Nigeria (Oladipupo \& Obazee, 2016) which wraps up that the tax penalty has a substantial impact on MSME tax compliance. Although there are tools to prevent tax avoidance in tax sanctions, the Directorate General of Taxation should still pay attention to other factors to improve taxpayer compliance. One way to explore other factors is to allow taxpayers to be closer to the authorities to assess their performance and provide feedback in the form of criticism or advice to the authorities. This performance assessment opportunity is defined as a quality factor in the tax authority's service that can affect taxpayer compliance.

The quality of tax services has proven to substantially influence MSME tax compliance as in a previous study in Zimbabwe (Maseko, 2014) and reinforced by recent research (Joseph \& Jacob, 2018) with a similar conclusion. Factors such as knowledge, sanctions, quality of service of tax authorities that in some previous studies were found to have a crucial influence on tax compliance are also supported by the influence factors of colleagues or neighbors (the effect of colleagues). A 2016 journal published by Tulane University said peer influence had a significant impact on tax filing and reporting decisions but did not guarantee increased taxpayer compliance (Alm et al., 2017). Risk preferences have a considerable negative moderating effect on the connection between taxpayer attitudes toward avoidance and taxpayer compliance (Alabede et al., 2011).

\section{Supporting Theory}

\subsection{Tax Compliance}

Based on the theory of obedience put forward by Tyler, there are two perspectives on legal compliance, called instrumental and normative. Instrumental perspectives assume individuals are driven by self-interest and response to behavioral change. (Tyler, 1990) Normative perspectives narrate what people identify as moral and opposed to their concerns. A person tends to obey the laws they deem appropriate and stick to their internal measures. Normative commitment based on morality implies obeying the rules because constituent authorities have the authority to prescribe behavior, whereas normative commitment based on legitimacy involves following the rules. After all, constituent authorities have the power to do so. Taxpayer compliance is considered necessary for increasing a country's tax receipts. According to Gunadi, tax compliance is the enthusiasm of residents to perform their contribution duties in line with existing legislation without the requirement for exams, inspections, cautions, or threats, as well as the application of legal and administrative punishments. (Savitri \& Musfialdy, 2016) The term "tax compliance" refers to a situation in which a taxpayer fulfills all of their tax obligations. As a result, taxpayers comply with the arrangements of tax laws and regulations, along with those who complete and implement them. (Devano \& Siti Rahayu, 2006)

\subsection{Tax Knowledge}

Fritz Heider built attribution theory in his dissertation to reveal the model of perception and perception of a person's object. Heider seeks to solve one of the philosophical problems in the phenomenon, the relationship between information sensors and real objects. Heider questions how a person can judge the quality of things in this world by wearing all the sensations on his mind. From his research, Heider proposes the theory that attribution processes are involved in a person's perception and that these perceptions are more complex than object perceptions. One sees the center of the action and can do things to others. People have abilities, desires, and sentiments; they can act intentionally and feel or see themselves. (Newcomb \& 
This theory can be used to explain how taxpayers comply with their tax obligations. A person will act in tax compliance when they get adequate tax information; in other words, when one's tax knowledge is high, then the tendency of tax compliance increases. Tax awareness or sensitivity refers to a taxpayer's understanding of tax regulations. Tax knowledge indicates the process in which tax legislation and other tax-related information are made available to taxpayers. Taxpayers' formal public education is critical in knowing tax regulations, particularly the need for registration and tax reporting. Citizens generally have little understanding of government spending and the costs of government-owned public services. As a result, taxpayers who do not have sufficient tax understanding must hire a tax counselor. Taxpayers' knowledge of taxation is one of the essential strategies to promote public awareness. (Oladipupo \& Obazee, 2016)

\subsection{Tax Sanctions}

Deterrent theory is a theory derived from behavioral psychology about preventing or controlling a person's actions or behavior by giving fear of punishment. (Hagan et al., 2018) Furthermore, the theory was developed in the field of economics. It produced a definition of the taxpayer's view as a rational economic agent that assesses costs (subject to fines or tax penalties) and benefits (determined by tax rates) to avoid paying taxes (not compliance).

The tax compliance research paradigm is based on economic prevention, connecting the financial and structural elements affecting compliance. The preventive economic strategy demonstrates that taxpayers consider cost-benefit analysis when determining the amount of tax owing, which is related to the rule of law in each country. Cost and benefit evaluations explain that compliance with low cost and benefit evaluations is a quick and easy procedure and quality service to realize tax compliance - prevention efforts to explain behavior changes rather than at the taxpayer compliance level. The economic model approach aims to identify causality in changes in taxpayer behavior in response to variable changes.

In short, sanctions are a particular measure used by tax authorities to give taxpayers a deterrent effect (Devos, 2014). The broader description of sanctions is that penalties for those who break the rules and fines are penalties for paying a certain amount of money for violations of applicable regulations and laws. And as a result, tax fines can be assumed to constitute unfavorable consequences for those who break the rules by paying a certain amount of penalties. Administrative sanctions and criminal sanctions are the two types of tax penalties legally recognized. Administrative sanctions, such as imposing fines, increases in tax payable, or interest, may be charged if a taxpayer executes negligence. The criminal charge is a (Savitri \& Musfialdy, 2016)

\subsection{Peer influence}

Three ways can be used to comprehend behavior: namely by models: 1) analytical, 2) sociological, and 3) the development of human relationships. The analytical model focuses on individuals of a rational organization with a diverse set of interests, needs, reasons, and goals. (Millett \& Simon, 1947) The human relationship modeling approach focuses more on the goals to be fulfilled and the development of various motivating systems according to the type of motivation to raise work productivity. Behavioral theory is the study of how people interact with one another. This method assumes that a person's social environment has an impact on their conduct. With this behavioral approach, the influence of colleagues or socialenvironmental pressures is considered to motivate or influence MSMEs taxpayers tend to comply if the surrounding environment complies in terms of taxation. Edlund and Aberg in 2002, Onu and Oats in 2014, and Bobek in 2013 stated that taxpayer behavior is defined by most of the social norms that determine taxpayer intent. (Edlund \& Åberg, 2002) Social norms are divided into four types, namely personal norms (self-anticipation based on appropriate behavior), descriptive norms (criteria that develop through monitoring how others behave in a particular status or situation), injunctive norms (standards that determine what to do based on what is approved and disapproved of by the group), the latter are subjective norms (anticipation from others that are significantly related to taxpayers e.g., friends, family, or co-workers (Alshirah et al., 2019). Suppose another person behaves in a socially acceptable mode of behavior. In that case, the individual will act appropriately, but when another person behaves socially rejected, the taxpayer's response will follow. The existence of social norms is consistent with the various conceptual frameworks of multiple disciplines, whether it depends on the effect of the bandwagon, conformity, social influence, adherence to authority, social capital, social networking, justice, belief, customs, tax morals, identifying morals, eliciting feelings of compassion, morality, and estrangement, as well as of patriotism or conscience (excommunicated) (Alm et al., 2017).

\subsection{Tax Authority Service Quality}

According to Crowding theory, a standardized liaison exists among external interventions (in this matter, how tax authorities communicate with taxpayers) and internal motivations (in this case, the tax behavior of individuals willing to pay taxes). (Osterloh \& Frey, 2000) Implicit or relational contracts can be used to model the interaction between taxpayers and taxing authorities. (Akerlof, 1982) Subjective associations have been strongly adopted to evaluate affiliations in the company (Osterloh \& Frey, 2000). The core concept is that exterior interferences, such as rewards or sanctions, can be used to reduce 
intrinsic drive. The officers are expected to be apprehensive of the Crowding theory's effects on taxpayer behavior. They attempt to decrease the burden of tax collection to enhance net tax receipts. They acknowledge that mistreating taxpayers weakens their tax attitude and, as a result, hikes the expenditure of taxes. The officers will only treat people with respect if there is an immense level of tax mindset. Contemporary tax officers recognize that tax payments are impacted by tax attitude and through external incentives. Offshore tax prevention should be utilized to keep taxpayers with low tax morale, or no moral taxes, from using them more honestly and refusing to pay their fair share. It is helpful to incorporate respectful and preventive care, and it is widely practiced, as demonstrated in the partial empirical. The association with this study is a person actuating obedient or disobedient conduct in completing his tax duties by using external factors, primarily the quality of tax authority services to MSMEs taxpayers, to assess obedient or rebellious behavior. According to Arum (2012), good physical services will provide comfort for taxpayers. Fiscus is supposed to be competent in terms of tax policy, administration, and law. He ought to have expertise, knowledge, and experience in these areas. (Melando \& Waluyo, 2013) According to Jatmiko (2016), service is a means of helping others (or prepare to take care of all the necessities that a person requires). Concurrently, the tax officer is the tax authority. As a result, tax authority services can be understood as a technique to assist the officers, manage, or equip all a person's essential purposes, which is a taxpayer-then, supplemented with Sapriadi (2013), which defines service quality as a public acknowledgment of the magnitude of the picture of the service supplied, whether the individual is content or not. The quality of service can validate customer expectations as a measure of the degree of service provided (Savitri \& Musfialdy, 2016).

\subsection{Risk Preferences}

Lead theory explains the occurrence of cognitive biases that affect decision-making in conditions of uncertainty and risk. Individuals will avoid risk or like risk depending on the problem at hand. (Tversky \& Kahneman, 1992) This theory holds that individuals will put excessive weight on the right results rather than the uncertain ones. This tendency increases risk avoidance behavior in favorable framing conditions. In positive framing, individuals show a decrease in risk preference, where individuals are more careful in making decisions. Conversely, individuals prefer the risk in certain circumstances of loss (negative framing). A negative structure is presented with the presentation of information about substantial losses. Sinking costs played a significant factor in the decision to continue with investments deemed to be less profitable. Sinking costs affect decision-makers in hostile framing conditions, thus encouraging individuals to like the risks that lead to increased commitment to failed actions (Keil et al., 2000).

Risk preference is a construct capable of incorporating perceived risk and the decision to take this risk. People tend to choose to avoid trouble, be neutral about existing threats, or look for hazards - and external factors such as decision-making goals can change a person's risk preferences. (Marth et al., 2020) Risk preferences can influence a person's decisions about the dangers they encounter as a taxpayer. (Torgler, 2003) The percentage of taxpayer compliance will be low when risk preferences have a direct correlation with it. Risk preferences were found to have a beneficial impact on taxpayer compliance in this study by Aryobimo and Cahyonowati (2012). In contrast, risk preferences had no compelling outcome on the submission of taxpayers in studies conducted (Saragih \& Aswar, 2020).

\section{Data and variables}

\subsection{Data and methodology}

The term "population" attributes to the total measurement of objects (units or individuals) whose attributes will be assessed. Population refers to all people, events, or interests which researchers want to investigate. In this study, the population used was small and medium business taxpayers throughout Indonesia. Due to the large number of MSME units scattered and time-constrained, this study reduces the scope of the sample of MSMEs entrepreneurs with several criteria in compliance with Law No. 20 of 2008 of the Republic of Indonesia, such as follows:

a. A micro business is a profitable firm controlled by a person or a single business entity with a maximum annual revenue of IDR 300,000,000.

b. Individuals or individual business entities with yearly revenues between IDR 300,000,000 and IDR 2,500,000,000 are considered small ventures.

c. Individuals or business entities with yearly revenues between IDR 2,500,000,000 and IDR 50,000,000,000 are classified as medium-sized enterprises.

d. According to Government Regulation No. 23 of 2018, businesses with annual revenue less than IDR 4,800,000,000 are subject to a final income tax of $0.5 \%$.

e. MSMEs operate online, sell products in an online marketplace or digital platform.

The analysis methods associated with this study are direct or primary data derived from the original or first source. Primary data collection is conducted with surveys, observations, and experiments. In this study, the researchers used questionnaire surveys to MSME taxpayers throughout Indonesia that were distributed online. Once the online questionnaires are collected and recapitulated, the next step is to test the data. The approach adopted in this research is a model of structural equations 


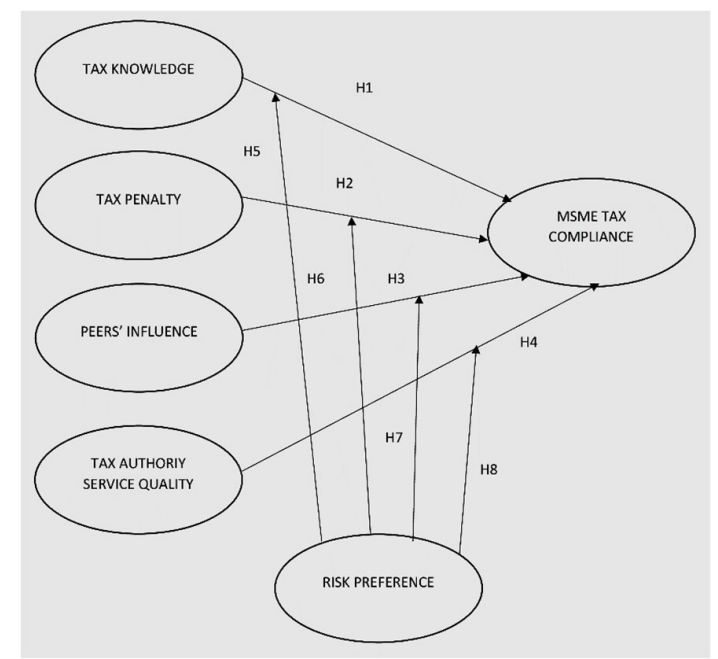

Fig. 1. Research Model

\section{Descriptive Statistics}

Researchers used online methods to distribute questionnaires to MSME taxpayers who conduct transactions digitally. The questionnaire closes with a choice of respondents' consent level answers on existing statements. Despite its closed nature, questionnaires distributed in this network can be accessed by all taxpayers throughout Indonesia. Taxpayers who receive questionnaire links are given a 1 (one) time opportunity to submit a response to avoid double data. Finding several respondents of MSME taxpayers who transact digitally in Indonesia to meet the number of samples was conducted for 12 days from September 24, 2020, to October 6, 2020. A total of 73\% of MSME taxpayers who transact digitally have a business domicile in Java Island, while the remaining $27 \%$ are outside Java Island. Most of the respondents involved in this study had more than one kiosk used for digital transactions; for example, a taxpayer can own stores on social media platforms Tokopedia, Shopee, and Instagram to sell products and process their orders. It is informed that 18 WP MSMEs who transact digitally also use media other than Tokopedia, Shopee, and social media accounts. These 18 WP MSMEs transact using GoFood, GrabFood, or SMS apps.

\subsection{Descriptive analysis of tax knowledge}

The result shows where $91 \%$ of MSME taxpayers agree and strongly agree that Tax ID Number (TIN/NPWP) is an identity for taxpayers to help soften their obligations to the state. The smallest average value of 3.39 is obtained from the indicator of knowledge in filling the tax return. As many as 59 respondents or $59 \%$ are in a state of hesitation, disagreement, and strongly disagree, which means that MSME taxpayers still do not correctly and adequately understand the filing of tax returns correctly and adequately.

\subsection{Descriptive analysis of tax sanctions}

In this case, $70 \%$ of MSME taxpayers agree and strongly agree that sanctions encourage taxpayers to comply with obligations. A minor average score of 3.41 was obtained from the sanction's indicators set by MSME taxpayers that made the law alarming, and as many as 51 respondents or 51\% agreed and strongly agreed, which means that MSME taxpayers are afraid. From the indicators and average values in the table above, there is a conclusion that the fear of MSME taxpayers keeps them motivated to register their tax reports.

\subsection{Descriptive analysis of peer influence}

In this situation, $62 \%$ of MSME taxpayers agree and strongly agree that the actions taken by MSME colleagues or acquaintances of businesses are included in their consideration when determining whether they want or not to report their taxes. The smallest average value of 3.10 was obtained from indicators of audit information acquisition and administrative tax sanctions. As many as 64 respondents or $64 \%$ expressed hesitation, disagreed, and strongly disagreed that they obtained sufficient information from their colleagues. From an average of 4 indicators describing the influence of colleagues, 33$37 \%$ of respondents have a doubtful or neutral answer and can conclude information about taxation circulating among them is not enough. 


\subsection{Descriptive analysis of the quality of tax authority services}

In this case, 59\% of MSME taxpayers agree and strongly agree that the friendliness of tax officials either directly/face-toface or indirectly (chats, digital conversations, telephone calls, and email conversations) is acceptable and felt by many MSME taxpayers. The most miniature average score of 3.25 came from the tax officer response-speed indicator. As many as 63 respondents or $63 \%$ expressed hesitation, disagreed, and strongly disagreed that they received a quick response from the tax officer who served their complaint. Of the average indicators describing the influence of colleagues, as high as $45 \%$ of respondents were undecided or neutral on the tax service response-speed indicator. The average of the ten quality indicators of taxation services that produce an average value in the range of 3 is proof that the quality is still in doubt. The slow response to the answer is less convincing, and MSMEs taxpayers still often find standard solutions such as templates from tax service admins on DJP social media accounts.

\subsection{Descriptive analysis of risk preferences}

This study shows that $90 \%$ of MSME taxpayers agree and strongly agree that businesses are the source of income and should be maintained. The smallest average value of 3.28 is obtained from the ease of financing indicators from financial institutions or governments that describe the financial risks of MSME taxpayers. As many as 58 respondents or 58\% expressed hesitation, disagreed, and strongly disagreed that MSMEs taxpayers get the ease in applying for credit or capital loans. In addition to these conclusions, it can also be seen that $73 \%$ of MSMEs taxpayers know the social risks of their business by listening to and receiving advice from other business owners.

\subsection{Descriptive analysis of tax compliance}

The research shows $79 \%$ of MSME taxpayers agree and strongly agree that this registration is crucial because it will be related to monthly and yearly tax reporting. The smallest average value of 3.63 was obtained from the indicator of the timely delivery of annual tax returns. As many as 90 respondents or $90 \%$ expressed hesitation, agreed, and strongly agreed that the submission of annual tax returns was carried out within a predetermined period by the government or tax authorities. From table 4.9 above, the researchers conclude that the utilization of computerized information supports the registration of MSMEs taxpayers and harvest their obligations and is evidenced by the average value on three indicators $4.02,4.03$, and 4.07 .

\section{Result}

The convergent validity of the item correlation was investigated in this study. According to the statistics, loadings and AVE values are more significant than 0.70 , but Alpha and CR values are less than 0.50 . These numbers demonstrated a high level of item correlation as well as valid convergent validity.

Table 1

Convergent validity

\begin{tabular}{lccccccc}
\hline Items & Loadings & Items & Loadings & Items & Loadings & Items & Loadings \\
\hline Mod-X5.1 & 0.741 & $\mathrm{X} 1.1$ & 0.626 & $\mathrm{X} 2.1$ & 0.617 & $\mathrm{X} 3.2$ & 0.754 \\
Mod-X5.1 & 0.738 & $\mathrm{X} 1.1$ & 0.79 & $\mathrm{X} 2.1$ & 0.695 & $\mathrm{X} 3.2$ & 0.853 \\
Mod-X5.2 & 0.624 & $\mathrm{X} 1.2$ & 0.742 & $\mathrm{X} 2.2$ & 0.527 & $\mathrm{X} 3.3$ & 0.807 \\
Mod-X5.2 & 0.717 & $\mathrm{X} 1.2$ & 0.883 & $\mathrm{X} 2.2$ & 0.626 & $\mathrm{X} 3.3$ & 0.918 \\
Mod-X5.3 & 0.78 & $\mathrm{X} 1.3$ & 0.755 & $\mathrm{X} 2.3$ & 0.805 & $\mathrm{X} 3.4$ & 0.858 \\
Mod-X5.3 & 0.86 & $\mathrm{X} 1.3$ & 0.753 & $\mathrm{X} 2.3$ & 0.883 & $\mathrm{X} 3.4$ & 0.928 \\
Mod-X5.4 & 0.834 & $\mathrm{X} 1.4$ & 0.729 & $\mathrm{X} 2.4$ & 0.721 & $\mathrm{X} 4.1$ & 0.688 \\
Mod-X5.4 & 0.876 & $\mathrm{X} 1.4$ & 0.863 & $\mathrm{X} 2.4$ & 0.853 & $\mathrm{X} 4.1$ & 0.872 \\
Mod-X5.5 & 0.773 & $\mathrm{X} 1.5$ & 0.732 & $\mathrm{X} 2.5$ & 0.775 & $\mathrm{X} 4.10$ & 0.804 \\
Mod-X5.5 & 0.918 & $\mathrm{X} 1.5$ & 0.843 & $\mathrm{X} 2.5$ & 0.874 & $\mathrm{X} 4.10$ & 0.941 \\
Mod-X5.6 & 0.744 & $\mathrm{X} 1.6$ & 0.579 & $\mathrm{X} 3.1$ & 0.731 & $\mathrm{X} 4.2$ & 0.684 \\
Mod-X5.6 & 0.911 & $\mathrm{X} 1.6$ & 0.661 & $\mathrm{X} 3.1$ & 0.844 & $\mathrm{X} 4.2$ & 0.87 \\
\hline
\end{tabular}

Table 2

The average variance extracted (AVE)

\begin{tabular}{|c|c|c|c|c|c|}
\hline Items & AVE & Square AVE & Items & AVE & Square AVE \\
\hline Assurance & 0.86 & 0.927 & Regulation & 0.719 & 0.848 \\
\hline Behaviour & 0.72 & 0.849 & Reliability & 0.823 & 0.907 \\
\hline BusinessSustainaibility & 0.837 & 0.915 & Responsiveness & 0.819 & 0.905 \\
\hline Empathy & 0.887 & 0.942 & RiskPreference & 0.566 & 0.752 \\
\hline FinancialRisk & 0.641 & 0.801 & SharingInfo & 0.852 & 0.923 \\
\hline Implementation & 0.746 & 0.864 & Tangibles & 0.758 & 0.871 \\
\hline Instrumental & 0.685 & 0.828 & TaxAuthorityServqual & 0.61 & 0.781 \\
\hline MetaCognitive & 0.816 & 0.903 & TaxCompliance & 0.646 & 0.804 \\
\hline Normative & 1 & 1 & TaxKnowledge & 0.536 & 0.732 \\
\hline PeersInfluence & 0.622 & 0.789 & TaxPenalty & 0.558 & 0.747 \\
\hline Procedural & 0.658 & 0.811 & & & \\
\hline
\end{tabular}


Table 3

Composite reliability and Cronbach's alpha

\begin{tabular}{|c|c|c|c|c|c|}
\hline Items & $\mathbf{C R}$ & CA & Items & $\mathbf{C R}$ & CA \\
\hline Assurance & 0.925 & 0.837 & Regulation & 0.837 & 0.612 \\
\hline Behaviour & 0.837 & 0.611 & Reliability & 0.903 & 0.785 \\
\hline BusinessSustainability & 0.911 & 0.805 & Responsiveness & 0.900 & 0.779 \\
\hline Empathy & 0.940 & 0.873 & RiskPreference & 0.886 & 0.844 \\
\hline FinancialRisk & 0.876 & 0.811 & SharingInfo & 0.920 & 0.826 \\
\hline Implementation & 0.855 & 0.660 & Tangibles & 0.863 & 0.681 \\
\hline Instrumental & 0.916 & 0.884 & TaxAuthorityServqual & 0.940 & 0.928 \\
\hline MetaCognitive & 0.899 & 0.774 & TaxCompliance & 0.916 & 0.889 \\
\hline Normative & 1.000 & 1.000 & TaxKnowledge & 0.852 & 0.783 \\
\hline PeersInfluence & 0.868 & 0.796 & TaxPenalty & 0.834 & 0.735 \\
\hline Procedural & 0.851 & 0.737 & & & \\
\hline
\end{tabular}

Table 4

Inner model R square

\begin{tabular}{lll}
\hline & R Square & R Square Adjusted \\
\hline TaxCompliance & 0.756 & 0.732 \\
\hline
\end{tabular}

From these numbers, the dependent variable can be described by independent variables with a substantial scale because $73.2 \%$ greater than $67 \%$ is the limit of criteria to determine whether the influence of dependent variables or not.

Table 5

Path Analysis

\begin{tabular}{lccc}
\hline Path Analysis & Original Sample $(\mathbf{O})$ & T Statistics $(|\mathbf{O} / \mathbf{S T D E V}|)$ & $\mathbf{t} 10 \%$ \\
\hline TaxKnowledge $\rightarrow$ MetaCognitive & 0.82 & 26.304 & 1.96 \\
TaxKnowledge $\rightarrow$ Procedural & 0.9 & 35.429 & 1.96 \\
TaxKnowledge $\rightarrow$ TaxCompliance & 0.279 & 3.469 & 1.96 \\
TaxPenalty $\rightarrow$ Implementation & 0.881 & 24.871 & 1.96 \\
TaxPenalty $\rightarrow$ Regulation & 0.866 & 29.963 & 1.96 \\
TaxPenalty $\rightarrow$ TaxCompliance & 0.157 & 1.899 & 1.96 \\
PeersInfluence $\rightarrow$ Behaviour & 0.876 & 34.101 & 1.96 \\
PeersInfluence $\rightarrow$ SharingInfo & 0.902 & 48.642 & 1.96 \\
PeersInfluence $\rightarrow$ TaxCompliance & 0.115 & 1.381 \\
TaxAuthorityServqual $\rightarrow$ Assurance & 0.897 & 1.96 \\
TaxAuthorityServqual $\rightarrow$ Empathy & 0.861 & 38.453 \\
TaxAuthorityServqual $\rightarrow$ Reliability & 0.877 & 1.96 \\
TaxAuthorityServqual $\rightarrow$ Responsiveness & 0.857 & 25.313 & 1.96 \\
TaxAuthorityServqual $\rightarrow$ Tangibles & 0.788 & 30.054 & 1.96 \\
TaxAuthorityServqual $\rightarrow$ TaxCompliance & 0.145 & 21.88 \\
RiskPreference*TaxKnowledge $\rightarrow$ TaxCompliance & 0.099 & 15.159 & 1.96 \\
RiskPreference*TaxPenalty $\rightarrow$ TaxCompliance & -0.199 & 1.957 & 0.223 \\
RiskPreference*PeersInfluence $\rightarrow$ TaxCompliance & 0.006 & 1.219 & 0.057 \\
RiskPreference*TaxAuthorityServqual $\rightarrow$ TaxCompliance & 0.092 & 1.909 & 0.953 \\
\hline
\end{tabular}

Ha1: Tax knowledge significantly influences the tax compliance of MSME taxpayers in digital transactions in Indonesia.

A t-statistical value of 3,469 proves there is a consequence of tax knowledge on the tax compliance level of MSMEs. The original sample value of 0.279 is a coefficient of parameters; it provides a significant influence, implying that the larger the level of tax awareness MSME taxpayers have, the steeper tax rate compliance MSME taxpayers possess. The first hypothesis (Ha1) is accepted or supported in conclusion.

Ha2: Tax sanctions significantly influence the tax compliance of MSME taxpayers in digital transactions in Indonesia.

The t-statistical value of 1,899 means that measurement results with a t-statistical amount lesser than 1.96 at a significance level of $10 \%$ is rejected, i.e., tax sanctions have no compelling impact on MSMEs tax compliance in digital transactions in Indonesia. While the original sample value of 0.157 is a coefficient of parameters which means a positive influence that increases MSME taxpayers' tax sanctions, the more tax compliance MSME taxpayers but Ha2 rejected.

Ha3: Peer influence significantly influences the tax compliance of MSME taxpayers in digital transactions in Indonesia.

Influence on the compliance of MSME taxpayers with the t-statistical value of 1,381 . The measurement result with a tstatistical rate smaller than 1.96 at a significance level of $10 \%$ means ha3 is rejected, i.e., peer influence doesn't influence immensely on MSME taxpayers' compliance in digital transactions in Indonesia. Conclusions are drawn from the significance level of $10 \%$ to conform to the research method in chapter III of this study. While the original sample value of 0.115 is a coefficient of parameters which means a positive influence that increases colleagues' impact from the MSME taxpayers' environment, the more tax compliance MSMEs taxpayers but Ha3 rejected. 
Ha4: The quality of tax authority services significantly influences the tax compliance of MSME taxpayers in digital transactions in Indonesia.

With the t-statistical value of 1,957 , we found the minor consequence of tax authority service quality on MSMEs' compliance. The measurement showed that the trait of assistance has no impact on MSME taxpayers' tax compliance in digital transactions in Indonesia. While the original sample value of 0.145 is a coefficient of parameters, it indicates a positive influence that boosts the tax authority service quality in MSME compliance.

Ha5: Risk preference significantly moderates the influence of tax knowledge on MSME taxpayer compliance in digital transactions in Indonesia.

With a t-statistical value of 1.219 , a t-statistical value less than 1.96 at a $10 \%$ significance level suggests ha5 is rejected, implying that risk preference is not significantly modifying the influence of familiarity of tax on MSME taxpayer compliance. While the original sample rate of 0.099 is a coefficient of parameters, it indicates that a positive moderation or risk preference strengthens the impact of tax knowledge towards taxpayer compliance.

Ha6: Risk preference moderates significantly the effect of tax sanctions on MSME taxpayer compliance in digital transactions in Indonesia.

With a t-statistical value of 1.909 , a t-statistical value less than 1.96 at a $10 \%$ significance level suggests ha6 is rejected, implying that risk preference does not significantly compromise tax penalties' influence on MSME taxpayer compliance. While the original sample rate of -0.199 is a coefficient of parameters, it indicates that a negative moderation or risk preference weakens the impact of tax sanctions towards taxpayer consent.

Ha7: Risk preference significantly moderates peer's influence on MSME taxpayer compliance in digital transactions in Indonesia.

With a t-statistical value of 0.059 , a t-statistical value less than 1.96 at a $10 \%$ significance level suggests ha7 is rejected, implying that risk preference is not significantly moderating the influence of peers' on MSME taxpayer compliance. While the original sample value of 0.006 is a coefficient of parameters, it indicates that a positive moderation or risk preference strengthens the impact of peers' influence towards taxpayer compliance.

Ha8: Risk preference moderates the tax authority service quality on MSME taxpayer compliance in digital transactions in Indonesia.

With a t-statistical value of 1.142 , a t-statistical value less than 1.96 at a $10 \%$ significance level suggests ha8 is rejected, implying that risk preference is not significantly moderating the influence of tax authority service quality on MSME taxpayer compliance. While the original sample value of 0.092 is a coefficient of parameters, it indicates that a positive moderation or risk preference strengthens the impact of tax authority service quality towards taxpayer compliance. Risk Preference as a moderation variable includes predictor moderating factor type because the influence on MSME taxpayer tax compliance variable (SME tax compliance) is significant directly to the dependent variable. Still, on test path and moderation path coefficient, the risk preference variable has no significant influence on four independent variables (tax knowledge, tax penalty, peers influence, and tax authority service quality).

\section{Conclusion}

This study proposes a model of MSME's tax compliance in a digital transaction. Tax knowledge has an evident, compelling influence on MSME taxpayers' tax compliance in digital transactions in Indonesia. In the digital age, MSME taxpayers use platforms such as social media to get the latest information on the latest news in taxation. They were mainly related to the taxation of digital transactions whose information is submitted to the public from 2019 but has not been implemented in the marketplace platform until August 2021. Tax sanctions do not affect MSME taxpayers' tax compliance in digital transactions in Indonesia due to special rules for the taxation of unfinished digital transactions, including sanctions if MSME taxpayers commit violations. Peer influence has no bearing on MSMEs' tax compliance in digital commerce. The community of MSMEs who transact using the marketplace has many sharing sessions between entrepreneurs about business strategies (prices, products, profit margins) but very few discussions about decisions related to taxation. Another thing is that most MSMEs consider that transactions conducted in the marketplace and their income do not include tax objects. The trait of tax authority assistance has an apparent but insignificant effect on the tax compliance of MSMEs taxpayers in digital transactions in Indonesia. Knowing the use of DJP communication media is considered inadequate. Tax and social media hotlines from DJP often experience disruptions such as no response when called; the official page of DJP that is down cannot be loaded in the browser. Another example is the response from standard social media admins such as templates, and other issues still require improvement. These MSMEs taxpayers will feel indistinguishable from corporate taxpayers 
with higher tax rates and more regular tax administration. Risk Preference is significantly influencing the tax compliance of MSME Taxpayers in digital transactions in Indonesia. From a money management perspective, risk preference usually refers to a tendency to determine actions that involve higher variances in potential budgetary issues relative to other options with more minor yield variants (but the expected value is the same). The risk preference is weighing strength, weakness, opportunity, and the threat from the business. The risk comes from external factors, including taxation rules from the authority and the motives shared by similar business owners. Risk mitigation determines the actions that MSME taxpayers will take including those related to their tax compliance.

\section{Declaration of conflicting interests}

The authors acknowledge that there is no conflict of interest.

\section{References}

Akerlof, G. A. (1982). Labor contracts as partial gift exchange. The quarterly journal of economics, 97(4), 543-569.

Alabede, J. O., \& Zainal Affrin, Z. (2011). Tax service quality and compliance behaviour in Nigeria: Do taxpayer's financial condition and risk preference play any moderating role?. European Journal of Economics, Finance and Administrative Sciences, (35), 90-108.

Alm, J., Bloomquist, K. M., \& McKee, M. (2017). When you know your neighbour pays taxes: Information, peer effects and tax compliance. Fiscal Studies, 38(4), 587-613.

Alshira'h, A. F., Abdul-Jabbar, H., \& Samsudin, R. S. (2019). The effect of tax moral on sales tax compliance among Jordanian SMEs. International Journal of Academic Research in Accounting, Finance and Management Sciences, 9(1), $30-41$.

Devano, S., \& Rahayu, S. K. (2006). Perpajakan: Konsep, teori, dan isu.

Devos, K. (2013). Do penalties and enforcement measures make taxpayers more compliant? The view of Australian tax evaders. Far East Journal of Psychology and Business, 12(1), 1-9.

Direktorat Jenderal Pajak. (2019). Laporan Kinerja Direktorat Jenderal Pajak Tahun 2019. Kementerian Keuangan Republik Indonesia Direktorat Jendral Pajak.

Edlund, J., \& Aberg, R. (2002). Social norms and tax compliance. Swedish economic policy review, 9(1), 201-231.

Hagan, J. L. (2018). Criminological controversies: A methodological primer. Routledge.

Joseph, J. K., \& Jacob, R. (2018). ANTECEDENTS OF TAX COMPLIANCE AMONG MSME'S UNDER GOODS AND SERVICE TAX [GST] REGIME: A CONCEPTUAL MODEL. International Journal of Social Science and Economic Research, 3(4), 1356-1371.

Kamil, N. I. (2015). The Effect of Taxpayer Awareness, Knowledge, Tax Penalties and Tax Authorities Services on the Tax Complience:(Survey on the Individual Taxpayer at Jabodetabek \& Bandung). Research Journal of Finance and Accounting, 6(2), 104-111.

Keil, M., Tan, B. C. Y., Wei, K. K., Saarinen, T., \& Tuunainen, V. V. and Wassenaar, A. 2000.'A cross-cultural study on escalation of commitment behaviour in software projects'. Mis Quarterly, 24(2), 299-325.

Marth, S., Sabitzer, T., Hofmann, E., Hartl, B., \& Penz, E. (2020). The Influence of Regulation on Trust and Risk Preference in Sharing Communities. Frontiers in Psychology, 11, 1369.

Maseko, N. (2014). The impact of personal tax knowledge and compliance costs on tax compliance behaviour of SMEs in Zimbabwe. Elite Research Journal of Accounting and Business Management, 2(3), 26-37.

Melando, N., \& Waluyo, W. (2013). Pengaruh Pelayanan Fiskus, Persepsi Atas Efektivitas Sistem Perpajakan, Pengetahuan Pajak, Dan Kesadaran Wajib Pajak Terhadap Kepatuhan Wajib Pajak Orang Pribadi. Ultimaccounting: Jurnal Ilmu Akuntansi, 5(2), 17-37.

Millett, C., \& Simon, H. A. (1947). Administrative behavior. A study of decision-making processes in administrative organization. New York: Free Press.

Mutmainah, D. A. (2016). Kontribusi UMKM Terhadap PDB Tembus Lebih Dari 60 Persen. CNN Indonesia.

Newcomb, T. (1958). The Psychology of Interpersonal Relations.

Oladipupo, A. O., \& Obazee, U. (2016). Tax knowledge, penalties and tax compliance in small and medium scale enterprises in Nigeria. IBusiness, 8(1), 1-9.

Osterloh, M., \& Frey, B. S. (2000). Motivation, knowledge transfer, and organizational forms. Organization science, 11(5), $538-550$

Rediyana, I., \& Mulya, H. (2019). Why Does The Tax Knowledge Give Negative Effect on the Level of Tax Payer Compliance?.

Ringle, C. M., Wende, S., \& Becker, J. M. (2015). SmartPLS 3. Boenningstedt: SmartPLS GmbH.

Saragih, T. R., \& Aswar, K. (2019). The Influencing Factors of Taxpayer Compliance: Risk Preferences as a Moderating Variable. International Journal of Academic Research in Accounting, Finance and Management Sciences, 9(4), 269278.

Sarpingah, S., Sormin, F., \& Handayani, R. (2017). Influence of Taxation Knowledge and Socialization of Implementation PP. 46 Year 2013 on Tax Compliance fo Certain WPOP Small and Medium Business (UMKM) Owner (Case Study in KPP Pratama Cengkareng, West Jakarta). Research Journal of Finance and Accounting, 8(2), 128-136.

Savitri, E. (2016). The effect of taxpayer awareness, tax socialization, tax penalties, compliance cost at taxpayer compliance 
with service quality as mediating variable. Procedia-Social and Behavioral Sciences, 219, 682-687.

Torgler, B. (2003). Tax morale: Theory and empirical analysis of tax compliance (Doctoral dissertation, University_of_Basel).

Tversky, A., \& Kahneman, D. (1992). Advances in prospect theory: Cumulative representation of uncertainty. Journal of Risk and uncertainty, 5(4), 297-323.

Tyler, T. R. (1990). Why people obey the law: Procedural justice. Legitimacy, and Compliance.

Waluyo, W. (2018, February). Tax Compliance in Small and Medium Enterprises (SMEs) in Indonesia. In Conference Proceedings Jakarta Indonesia, ICABE 2018.

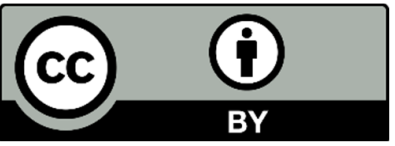

(C) 2022 by the authors; licensee Growing Science, Canada. This is an open access article distributed under the terms and conditions of the Creative Commons Attribution (CC-BY) license (http://creativecommons.org/licenses/by/4.0/). 